\title{
Quality and Safety of Camel Milk along the Value Chain in Eastern Ethiopia
}

\author{
Mulugojjam Adugna $^{\mathrm{a}}$, Eyassu Seifub ${ }^{\mathrm{b}, c^{*}}$, Ameha Kebeded $^{\mathrm{d}}$, And Reiner Doluschitz ${ }^{\mathrm{e}}$ \\ a Department of Biology, Debre Tabor University, P.O.Box 272, Debre Tabor, Ethiopia \\ ${ }^{\mathrm{b}}$ Department of Animal Sciences, Haramaya University, P.O.Box 287, Haramaya campus, Ethiopia \\ ${ }^{c}$ Department of Food Science and Technology, Botswana College of Agriculture, Private Bag 0027, Gaborone, \\ Botswana \\ ${ }^{\mathrm{d}}$ Department of Biology, Haramaya University, P.O.Box 138, Dire Dawa, Ethiopia \\ e Department of Farm Management (410C), University of Hohenheim 70593, Stuttgart, Germany \\ ${ }^{*}$ Corresponding author \\ eyassu_seifu@yahoo.com \\ TEL: $+(251) 255530370$ \\ FAX: $+(251) 255530325$
}

Received: 25 June 2012; Published online: 18 October 2013

\begin{abstract}
The safety of camel milk was assessed along the value chain in Erer, eastern Ethiopia. A total of 24 camel milk samples were aseptically collected from producers in Erer $(n=12)$, and wholesalers and retailers $(n=12)$ along the chain. Milk quality parameters were analyzed following standard procedures. The mean $( \pm \mathrm{SD})$ total bacteria (TBC), Enterobacteriaceae (EC), coliform (CC), spore-forming bacteria (SFBC) and yeast and mould (YMC) counts of the milk samples analyzed were 5.2 $\pm 1.90,3.2 \pm 2.30$, $2.9 \pm 2.27,2.1 \pm 2.41$ and $2.7 \pm 1.61 \log _{10} \mathrm{cfu} \mathrm{mL}^{-1}$, respectively. The TBC, EC, CC and SFBC of milk samples obtained from retailers in the final marketing sites were significantly higher $(\mathrm{P}<0.05)$ than those obtained from producers and wholesalers in Erer. Salmonella spp. was detected in milk samples collected from all sites. Other microorganisms isolated from camel milk samples include Staphylococcus aureus (16.2\%), Entrobacter spp. (14.9\%), Streptococcus spp. (13.5\%), Escherichia coli (8.1\%), Acinetobacter spp. (7.4\%), Staphylococcus epidermidis (6.8\%), Klebsiella spp. (6.1\%), Bacillus spp. (5.4\%), Corynebacterium spp. (5.4\%), Micrococcus spp. (4.7\%), Lactobacillus spp. (4.1\%), Listeria spp. (4.1\%), Pseudomonas spp. (2\%) and Shigella spp. (1.4\%). The quality of camel milk produced in the study area was generally poor and microbial contamination of camel milk occurs along the value chain while it is transported from the production site to the market. This calls for strict hygienic measures along the entire value chain in order to improve the quality and safety of camel milk produced in the area evaluated.
\end{abstract}

Keywords: Camel milk; Public health; Safety; Value chain

\section{Introduction}

Ethiopia possesses about 2.4 million dromedary camels that places the country third in the World in camel population (FAOSTAT, 2009). The majority of camels are found in the drier areas of the eastern part of the country. Because of their outstanding performance in the arid and semiarid areas of the eastern lowlands of Ethiopia, pastoralists rely mainly on camels for their livelihood. In these areas, camels are mainly kept for milk production and produce milk even during the dry season when milk from cattle is scarce (Tafesse, Mekuriaw, \& Baars, 2002). The annual 
camel milk production in Ethiopia is estimated to be 247,100 metric tons (FAOSTAT, 2010).

Contamination of milk takes place during milking, from the udder, milking equipment or milking personnel. Furthermore, contamination occurs during transportation and storage of the milk. Under any of these conditions, microorganisms get into the milk and multiply. The microbial load of milk is determined by the distance between the farm, the processing plant and the consumers, the time lapsed during transportation of milk from the farm to the consumers, and the temperature of milk during storage and transportation which gives bacteria the chance to adapt and grow in this nutritious liquid (Semereab \& Molla, 2001).

Erer is an important camel milk producing area in eastern Ethiopia. Milk is produced from pastorally managed camels, under traditional conditions, and camels are milked by hand. Large volumes of camel milk is produced and sold daily in the area. However, the milk is not pasteurized, handled under poor hygienic conditions, transported long distance $(\approx 80 \mathrm{~km})$ without a refrigeration system and sold on open markets or distributed to retailers. Thus, milk transported and handled under such conditions would have poor quality and may contain pathogenic microorganisms of public health concern.

Therefore, assessing the quality and safety of camel milk along the value chain, that is, from primary production site until it reaches the final market is of paramount importance in order to devise appropriate intervention strategies aimed at improving its quality and safety. This study was conducted to assess the quality and safety of raw camel milk collected along the value chain in Erer, eastern Ethiopia.

\section{Materials and Methods}

\subsection{Description of the study area}

The study was conducted along the camel milk chain between Erer and Dire Dawa town. Erer is the primary camel milk production site located in the Babile administration at $9^{\circ} 08^{\prime} 40^{\prime \prime}$ $\mathrm{N}$ latitude and $42^{\circ} 21^{\prime} 30^{\prime \prime} \mathrm{E}$ longitude in eastern Ethiopia whereas Harar and Dire Dawa are the major camel milk marketing sites along this route. Harar and Dire Dawa are the major urban centres in eastern Ethiopia and are located 30 and $80 \mathrm{~km}$ from Erer, respectively. Large volumes of camel milk are transported daily from Erer to Harar and Dire Dawa towns by wholesalers who collect milk directly from the producers in Erer. The milk is placed in plastic containers (jerry cans) and transported by minibus without any refrigeration system and sold to urban consumers in Harar and Dire Dawa towns.

\subsection{Raw milk sample collection}

A total of 24 camel milk samples $(\approx 500 \mathrm{~mL}$ each) were collected from selected households, wholesalers and retailers along the value chain. Morning milk (first milk obtained in the morning) was taken from the containers of 12 randomly selected households (producers) in Erer. In addition, 12 samples of camel milk were collected from wholesalers and retailers at selected marketing points along the value chain (6 from Erer, 3 from Harar and 3 from Dire Dawa). The camel milk samples were collected aseptically using sterile bottles and transported to Haramaya University Dairy Laboratory by placing them in an icebox. The milk samples were kept at $4^{\circ} \mathrm{C}$ in a refrigerator until laboratory analysis.

\subsection{Physico-chemical properties}

Temperature of the milk samples was determined by a thermometer at the collection site and $\mathrm{pH}$ was measured by digital pH Meter (O'Connor, 1995 ) in the laboratory. Titratable acidity and specific gravity of the milk were also determined according to O'Connor (1995).

\subsection{Microbiological assessment}

\section{Total bacterial count}

Milk samples $(25 \mathrm{~mL})$ were diluted in 225 $\mathrm{mL}$ peptone water (Himedia, M028, India) and mixed thoroughly. After preparation of serial dilutions up to $10^{-8}$, volumes $(1 \mathrm{~mL})$ of appropriate dilutions were plated by the pour plate technique in duplicate using standard plate count 
agar (Oxoid, UK). Colonies were counted after incubation at $32^{\circ} \mathrm{C}$ for 48 hours (Roberts \& Greenwood, 2003).

\section{Coliform count}

Volumes $(1 \mathrm{~mL})$ of appropriate dilutions were plated by the pour plate technique in duplicate using Violet Red Bile Agar (Himedia, V37720-2I, India) and the plates were incubated at $30^{\circ} \mathrm{C}$ for 24 hours. Pink colonies surrounded by bile precipitation were counted as coliforms (Roberts \& Greenwood, 2003).

\section{Enterobacteriaceae count}

Volumes $(1 \mathrm{~mL})$ of appropriate dilutions were plated by the pour plate technique in duplicate using Violet Red Bile Glucose Agar (Himedia, V37720-2I, India) and plates were incubated at $37^{\circ} \mathrm{C}$ for 24 hours. Pink to red purple colonies surrounded by red zone of precipitated bile were considered as Enterobacteriaceae (Roberts \& Greenwood, 2003).

\section{Spore-forming bacteria count}

Milk samples were first heat treated in a water bath at $80^{\circ} \mathrm{C}$ for 10 minutes and volumes $(1 \mathrm{~mL})$ of appropriate dilutions were pour plated as for the standard plate count using plate count agar (Oxoid, UK). Colonies were counted after incubation at $30^{\circ} \mathrm{C}$ for 3 days (Roberts \& Greenwood, 2003).

\section{Yeast and mould count}

Volumes $(1 \mathrm{~mL})$ of appropriate dilutions of milk samples were plated by the pour plate technique in duplicate using potato dextrose agar (Himedia, MU096, India) supplemented with streptomycin. Colonies were counted after incubating the plates at $25^{\circ} \mathrm{C}$ for 5 days (McLandsborough, 2004).

\subsection{Identification of the dominant microflora}

For identification of the general microflora, $10 \%$ of the colonies ( $24 \mathrm{~h}$ old) grown on standard plate count agar were picked at random and purified by repeated plating. The colonies were subjected to different morphological (cell shape, motility, cell grouping and endospores), biochemical (catalase, oxidation-fermentation, carbohydrate utilization, indole and Methyl red-VogesProskauer $(\mathrm{Mr}-\mathrm{Vp}))$ and physiological $(\mathrm{KOH})$ tests and identified to genus and species levels (Harley \& Prescott, 2002; Yi-Wei \& Stratton, 2006; Goldman \& Green, 2009).

\subsection{Detection of selected pathogens}

\section{Detection of Salmonella species}

Salmonella spp.was detected according to the procedure outlined by the Food and Drug Administration (FDA, 2001). Twenty five $\mathrm{mL}$ of milk was pre-enriched in $225 \mathrm{~mL}$ of buffered peptone water at $37^{\circ} \mathrm{C}$ for 24 hours. Then, $10 \mathrm{~mL}$ of pre-enrichment sample was incubated in Selenite Cystine Broth (Blulux, India) at $42^{\circ} \mathrm{C}$ for 24 hours. About $0.1 \mathrm{~mL}$ of the selective enrichment was then streaked onto Xylose Lysine Desoxycholate agar (Himedia, M031, India) plates. The plates were then incubated at $37^{\circ} \mathrm{C}$ for 24 hours. Cells of typical colonies with large, glossy black centres or that appear almost completely black were picked and observed under the microscope to determine their cell arrangement and shape.

\section{Detection of Escherichia coli O157:H7}

After preparation of serial dilutions, $0.1 \mathrm{~mL}$ of the sample was spread evenly onto the surface of Sorbitol MacConkey agar (Himedia, M298, India). The inoculated Petri plates were then incubated at $35^{\circ} \mathrm{C}$ for $18-24 \mathrm{~h}$. Colonies that were sorbitol-negative, which had pale colour, and which were indole, L-Arabinose and mannitolpositive were considered as E. coli O157:H7 (FDA, 2001; Leclercq, Lambert, Pierard, \& Mahillon, 2001).

\section{7 $\quad$ Statistical analysis}

The physicochemical and microbial count data obtained from the four sampling sites were com- 
pared, and analyzed by the analysis of variance technique, using SAS software. Microbial count data was first transformed to $\log _{10}$ before statistical analysis. Mean separation was carried out using the Tukey's Honestly Significant Test when analysis of variance showed a significant difference between means.

\section{Results and Discussion}

\subsection{Physical properties of camel milk}

The mean values of temperature, $\mathrm{pH}$, titratable acidity and specific gravity of camel milk collected along the value chain between Erer and Dire Dawa are shown in Table 1. The pH of the milk samples progressively decreased from the time the milk was collected from the producers until it reached the final market in Dire Dawa (Table 1) which takes about three hours while acidity followed the opposite trend. The $\mathrm{pH}$ of the milk samples collected from Harar and Dire Dawa markets were significantly $(\mathrm{p}<0.05)$ lower than the $\mathrm{pH}$ of milk samples collected from producers at Erer (Table 1). The acidity of camel milk observed in the present study is in line with the findings of Khaskheli, Arain, Chaudhry, Soomro, and Qureshi (2005) who reported that acidity of camel milk expressed in terms of lactic acid content varied between 0.12 to $0.2 \mathrm{~g}$ per $100 \mathrm{~g}$, with an average of $0.18 \pm 0.01 \mathrm{~g}$ per 100 g. The low pH of camel milk samples at the final markets indicates increased acid production due to multiplication of microorganisms in the milk during transportation and storage at the vending sites. The specific gravity of milk samples collected from all sites lies within the normal range (1.025-1.032) for the specific gravity of camel milk (Farah, 1996).

\subsection{Microbial counts}

Table 2 presents the mean microbial counts of camel milk collected along the value chain between Erer and Dire Dawa. The total bacterial count (TBC) of milk samples obtained from Dire Dawa retailers was significantly $(\mathrm{p}<0.05)$ higher than milk samples obtained from wholesalers and producers in Erer while the TBC of milk samples obtained from producers in Erer was significantly lower $(\mathrm{p}<0.05)$ than the rest. An increase in TBC was observed along the chain as the milk was transported from the production site until it reached the final markets in Harar and Dire Dawa towns. The higher TBC at the final markets could be attributed to the long distance that the milk is transported from the production site and time required to travel this long distance without refrigeration. It often takes 2-3 $\mathrm{h}$ to deliver milk to the final markets and milk is transported by minibus without use of any cooling system. The high TBC could have also partly be attributed to improper handling of milk during transportation, collection and storage at the vending sites.

High total bacterial counts in raw milk mainly reflect the poor hygienic condition under which the milk was handled, that is, storage temperature and time elapsed since milking and the poor health of milking animals (Hayes \& Boor, 2001). The overall mean (5.15 $\left.\log _{10} \mathrm{cfu} \mathrm{mL}^{-1}\right)$ TBC observed in this study is in agreement with the values $5 \log _{10} \mathrm{cfu} \mathrm{mL}^{-1}, 5.4 \log _{10} \mathrm{cfu} \mathrm{mL}^{-1}$ and $5.6 \log _{10} \mathrm{cfu} \mathrm{mL}^{-1} \mathrm{TBC}$ reported by $\mathrm{Al}-$ Mohizea (1994), Semereab and Molla (2001), ElZiney and Al-Turki (2007), respectively for camel milk. Merin, Sela, Rosen, Pinto, and Leitner (2005) reported that camel milk bacterial quality is often not up to the accepted standards of bovine milk which suggests that milk from individual producers should not exceed $1 \times 10^{5}$ cfu $\mathrm{mL}^{-1}$ prior to commingling and $3 \times 10^{5} \mathrm{cfu}$ $\mathrm{mL}^{-1}$ as commingled milk prior to pasteurization. It is also in line with the value $5.25 \log _{10}$ cfu $\mathrm{mL}^{-1}$ for aerobic plate count reported by Omer and Eltinay (2008) for camel milk in the United Arab Emirates. However, it is lower than the total bacterial counts of Somali camel milk collected from production farms (7.43 $\log _{10} \mathrm{cfu}$ $\left.\mathrm{mL}^{-1}\right)$, a primary collection site $\left(8.84 \log _{10} \mathrm{cfu}\right.$ $\left.\mathrm{mL}^{-1}\right)$, a local market $\left(8.83 \log _{10} \mathrm{cfu} \mathrm{mL}^{-1}\right)$ and a distance market $\left(9.23 \log _{10} \mathrm{cfu} \mathrm{mL}^{-1}\right)$ (Younan et al., 2004). The microbiological quality of raw milk should be of major concern to the producers, the processors and the general public because bacteria in milk can degrade milk components, decrease shelf life and acceptability of processed products, and cause illnesses in human beings 
Table 1: Physical properties (means $\pm \mathrm{SD}$ ) of camel milk produced and marketed along the value chain between Erer and Dire Dawa.

\begin{tabular}{llllll}
\hline Sampling site & $\mathrm{n}$ & $\begin{array}{l}\text { Temperature } \\
\left({ }^{\circ} \mathrm{C}\right)\end{array}$ & $\mathrm{pH}$ & $\begin{array}{l}\text { Titratable acidity } \\
(\% \text { lactic acid) }\end{array}$ & Specific gravity \\
\hline Erer producers & 12 & $29.8 \pm 1.42^{c}$ & $6.70 \pm 0.135^{a}$ & $0.156 \pm 0.038$ & $1.030 \pm 0.002^{b a}$ \\
Wholesalers & 6 & $31.3 \pm 1.21^{b c}$ & $6.59 \pm 0.128^{b a}$ & $0.157 \pm 0.052$ & $1.029 \pm 0.002^{b a}$ \\
Harar retailers & 3 & $33.3 \pm 2.89^{a b}$ & $6.43 \pm 0.108^{b}$ & $0.170 \pm 0.012$ & $1.026 \pm 0.004^{b}$ \\
D/D retailers & 3 & $34.7 \pm 0.58^{a}$ & $6.39 \pm 0.060^{b}$ & $0.220 \pm 0.006$ & $1.032 \pm 0.002^{a}$ \\
Overall mean & 24 & $31.3 \pm 2.28$ & $6.60 \pm 0.170$ & $0.166 \pm 0.042$ & $1.030 \pm 0.003$ \\
\hline
\end{tabular}

Means with different superscript letters in a column are significantly different $(\mathrm{P}<0.05) ; \mathrm{SD}=$ standard deviation; $\mathrm{n}=$ number of samples; $\mathrm{D} / \mathrm{D}=$ Dire Dawa.

Table 2: Mean $( \pm \mathrm{SD})$ microbial counts $\left(\log _{10} \mathrm{cfu} \mathrm{mL}^{-1}\right)$ of camel milk produced and marketed along the value chain between Erer and Dire Dawa.

\begin{tabular}{lllllll}
\hline Sampling sites & $\mathrm{n}$ & TBC & EC & CC & SFBC & YMC \\
\hline EP & 12 & $4.14 \pm 0.74^{c}$ & $1.65 \pm 1.87^{c}$ & $1.24 \pm 1.55^{c}$ & $0.79 \pm 1.17^{b}$ & $1.89 \pm 1.46$ \\
WS & 6 & $4.80 \pm 0.33^{b c}$ & $3.56 \pm 0.43^{b c}$ & $3.26 \pm 0.31^{b}$ & $0.90 \pm 0.99^{b}$ & $3.28 \pm 1.80$ \\
HR & 3 & $6.74 \pm 0.59^{b a}$ & $6.69 \pm 0.65^{a}$ & $6.66 \pm 0.48^{a}$ & $5.86 \pm 0.07 \mathrm{a}$ & $3.72 \pm 0.15$ \\
DR & 3 & $8.27 \pm 3.62^{a}$ & $5.41 \pm 0.64^{b a}$ & $5.08 \pm 0.20^{b a}$ & $5.85 \pm 0.02^{a}$ & $3.90 \pm 1.16$ \\
OM & 24 & $5.15 \pm 1.90$ & $3.23 \pm 2.30$ & $2.90 \pm 2.26$ & $2.08 \pm 2.41$ & $2.72 \pm 1.61$ \\
\hline
\end{tabular}

Means with different superscript letters in a column are significantly different $(\mathrm{P}<0.05) ; \mathrm{EP}=$ Erer producers; $\mathrm{WS}=$ Wholesalers; $\mathrm{HR}=$ Harar retailers; $\mathrm{DR}=$ Dire Dawa retailers; $\mathrm{n}=$ number of samples; $\mathrm{SD}=$ standard deviation; $\mathrm{OM}=$ Overall mean value; $\mathrm{TBC}=$ Total bacterial count $\mathrm{EC}=$ Enterobacteriaceae count $\mathrm{CC}=$ Coliform count; $\mathrm{SFBC}=$ Spore-forming bacteria count; YMC = Yeast and mould count.

(Hayes \& Boor, 2001).

The Enterobacteriaceae count (EC) of camel milk samples obtained from Harar retailers was significantly $(\mathrm{p}<0.05)$ higher than the EC of milk samples obtained from wholesalers and producers in Erer (Table 2), whereas the EC of milk samples obtained from producers in Erer was significantly $(\mathrm{p}<0.05)$ lower than that obtained from retailers in Harar and Dire Dawa (Table $2)$. The overall mean EC $\left(3.23 \log _{10} \mathrm{cfu} \mathrm{mL}^{-1}\right)$ observed in this study is greater than the value $\left(2.72 \log _{10} \mathrm{cfu} \mathrm{mL}^{-1}\right)$ reported by El-Ziney and Al-Turki (2007) for camel milk. An increase in EC was observed along the chain as the milk was transported from the production site until it reached the final markets. The high EC count in the camel milk samples should be a public health concern because most members of the family Enterobacteriaceae are pathogenic and can cause illnesses in human beings.

The coliform count (CC) of camel milk samples obtained from Harar retailers was significantly $(\mathrm{p}<0.05)$ higher than the $\mathrm{CC}$ of milk samples obtained from wholesalers and producers in Erer (Table 2). The CC of milk samples obtained from producers was significantly $(\mathrm{p}<0.05)$ lower than the rest (Table 2). The overall mean CC (2.9 $\log _{10}$ cfu $\mathrm{mL}^{-1}$ ) observed in this study is greater than the value $\left(1.4 \log _{10} \mathrm{cfu} \mathrm{mL}^{-1}\right)$ reported by El-Ziney and Al-Turki (2007) for camel milk produced in Saudi Arabia. However, it is in line with the value $2.83 \log _{10}$ cfu $\mathrm{mL}^{-1}$ reported by Omer and Eltinay (2008) for coliforms in camel milk produced in the United Arab Emirates.

Spore-forming bacteria counts (SFBC) of camel milk samples obtained from Harar and Dire Dawa retailers were significantly $(\mathrm{p}<0.05)$ higher than those of milk samples obtained from wholesalers and producers in Erer (Table 2). The overall mean SFBC $\left(2.1 \log _{10} \mathrm{cfu} \mathrm{mL}^{-1}\right)$ observed in this study is comparable with the result of ElZiney and Al-Turki (2007) who reported a mean SFBC of $2.1 \log _{10}$ cfumL $^{-1}$ for camel milk in the Qassim region of Saudi Arabia. Spore-forming bacteria, apart from causing spoilage, are known to cause food-poisoning by producing heat-stable 
enterotoxins (Britz \& Robinson, 2008). They are commonly found in the soil, feed and on the udder where the risk of contamination of teats with soil is greatest (Hayes \& Boor, 2001).

Although an increase in yeast and mould count (YMC) was observed along the chain as the milk was transported from the production site until it reached the final markets in Harar and Dire Dawa, no significant difference $(\mathrm{p}>0.05)$ was observed in YMC among the different milk samples. The overall mean YMC $\left(2.72 \log _{10} \mathrm{cfu} \mathrm{mL}^{-1}\right)$ observed in this study is greater than the YMC (1.9 $\log _{10} \mathrm{cfu} \mathrm{mL}^{-1}$ ) reported by El-Ziney and AlTurki (2007) for camel milk. However, it is in line with the YMC $\left(2.61 \log _{10} \mathrm{cfu} \mathrm{mL}^{-1}\right)$ reported by Omer and Eltinay (2008) for camel milk in the United Arab Emirates. Yeasts and moulds are considered to be spoilage organisms. Some yeasts and moulds, however, are public health concerns due to production of mycotoxins, which are not destroyed during food processing or cooking (McLandsborough, 2004).

In general, an increase in all microbial counts was observed along the chain starting from the production site until the milk reached final markets. All the microbial counts of camel milk samples obtained from Harar and Dire Dawa retailers were generally higher than microbial counts of milk samples obtained from wholesalers and producers in Erer. This confirms multiplication of microorganisms in milk as the milk is transported from the production site until it reaches the final markets.

\subsection{General microflora identified}

Milk samples obtained from producers in Erer mainly contained bacteria belonging to the genera Staphylococcus, Streptococcus, Entrobacter, Klebsiella, Escherichia, Acinetobacter, Micrococcus and Lactobacillus, while milk obtained from wholesalers and retailers in Harar and Dire Dawa additionally contained high percentages of bacteria of environmental origin such as Bacillus and Corynebacterium (Table 3). The most prevalent microorganisms isolated from camel milk samples, obtained both from producers and vendors, were members of the genera Staphylococcus, Streptococcus, Acinetobacter, and Entrobac- ter and the species Escherichia coli.

Most of the bacterial genera identified are potentially pathogenic because they contain species that are pathogenic and can cause disease if ingested. The risk of contamination of milk with pathogens is attributed to the practice of mixing milk from different sources, poor hygiene and handling practice of camel milk along the chain and absence of cooling facilities. In order to control the risk associated with consumption of raw camel milk, it is important to apply proper hygienic measures, starting from the production farm until the milk reaches final vending sites and the consumers, as well as heat treatment of milk such as pasteurization.

\subsection{Pathogens detected}

Salmonella spp. was identified in $66.4 \%$ of milk samples collected from producers in Erer, $83.3 \%$ of milk samples collected from wholesalers, and in all of the milk samples collected from Harar and Dire Dawa retailers. However, Escherichia coli O157:H7 was not detected in any of the milk samples. High contamination of milk with Salmonella was observed at retail markets in Harar and Dire Dawa. This confirms that the chance of contamination with Salmonella increases as the milk is transported from the production site to the market. Although no confirmation test was carried out to identify the specific species/strain of Salmonella in this study, detection of the genus Salmonella in the camel milk samples is of major public health concern since all Salmonella species are pathogenic. This calls for proper production and transportation of milk, appropriate hygienic measures, and mandatory pasteurization of milk before sale.

\section{Conclusions}

This study showed that the quality of camel milk produced and marketed along the value chain, that is, starting from the primary production site in Erer until it reaches final markets in Harar and Dire Dawa was poor. The high microbial counts and detection of high levels of pathogens, such as Salmonella, in milk samples collected from the final marketing sites shows that microbial con- 
Table 3: Frequency of occurrence of bacterial species/genera in raw camel milk samples collected along the value chain between Erer and Dire Dawa.

\begin{tabular}{|c|c|c|c|c|c|c|c|c|c|c|c|c|c|c|}
\hline Milk source & 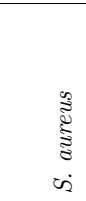 & 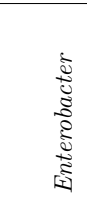 & 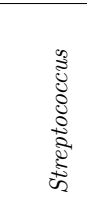 & $\begin{array}{l}: \widetilde{8} \\
\text { 점 }\end{array}$ & 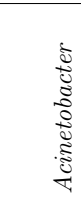 & 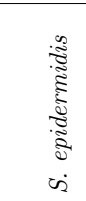 & 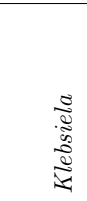 & 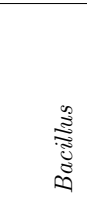 & 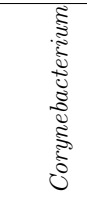 & 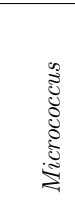 & 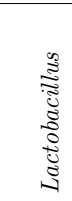 & & 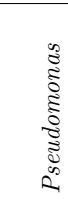 & 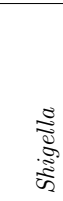 \\
\hline \multirow{2}{*}{ Erer producers $(n=74)$} & 11 & 10 & 10 & 7 & 6 & 4 & 8 & 0 & 0 & 6 & 5 & 4 & 2 & 1 \\
\hline & $(14.9)$ & $(13.5)$ & $(13.5)$ & $(9.5)$ & $(8.1)$ & $(5.4)$ & $(10.8)$ & 0 & 0 & $(8.1)$ & $(6.8)$ & $(5.4)$ & $(2.7)$ & (1.4) \\
\hline \multirow{2}{*}{ Wholesalers $(\mathrm{n}=36)$} & 6 & 9 & 7 & 5 & 2 & 3 & 1 & 1 & 1 & 0 & 0 & 1 & 0 & 0 \\
\hline & $(16.7)$ & -25 & $(19.4)$ & $(13.9)$ & $(5.6)$ & $(8.3)$ & $(2.8)$ & $(2.8)$ & $(2.8)$ & 0 & 0 & $(2.8)$ & 0 & 0 \\
\hline \multirow{2}{*}{ Harar retailers $(n=19)$} & 6 & 2 & 1 & 0 & 1 & 1 & 0 & 3 & 2 & 0 & 0 & 1 & 1 & 1 \\
\hline & $(31.6)$ & $(10.5)$ & $(5.3)$ & 0 & $(5.3)$ & $(5.3)$ & 0 & $(15.6)$ & $(10.5)$ & 0 & 0 & $(5.3)$ & $(5.3)$ & $(5.3)$ \\
\hline \multirow{2}{*}{$\begin{array}{r}\text { Dire Dawa retailers } \\
\qquad(\mathrm{n}=19)\end{array}$} & & 1 & 2 & 0 & 2 & 2 & 0 & 4 & 5 & 1 & 1 & 0 & 0 & 0 \\
\hline & $(5.3)$ & $(5.3)$ & $(10.5)$ & 0 & $(10.5)$ & $(10.5)$ & 0 & $(21.1)$ & $(26.3)$ & $(5.3)$ & $(5.3)$ & 0 & 0 & 0 \\
\hline
\end{tabular}

$\mathrm{n}=$ number of isolates from camel milk samples collected from the respective sites; $\mathrm{S}=$ Staphylococcus; E. Escherichia; Values in parenthesis are percentages of the total bacterial isolates.

tamination of camel milk occurs along the value chain while it is transported from the production farms to final markets. Thus, this calls for heat treatment of milk and strict hygienic measures along the entire value chain in order to improve the quality and safety of camel milk produced and marketed in the study area.

\section{Acknowledgements}

This study was funded by the Ministry of Education of Ethiopia. The Food Security Center of Hohenheim University is acknowledged for provision of a postdoctoral research scholarship and assistance during preparation of this manuscript.

\section{References}

Al-Mohizea, I. (1994). Microbial quality of camel's milk in riyadh markets. Egyptian Journal of Dairy Science, 14, 469-487.

Britz, T., \& Robinson, R. (2008). Advanced dairy science and technology. Oxford: Blackwell Publishing Ltd.

El-Ziney, M., \& Al-Turki, A. (2007). Microbiological quality and safety assessment of camel's milk (Camelus dromedarius) in Saudi Arabia (Qassim Region). Applied Ecology and Environmental Research, 5(2), 115-122.
FAOSTAT. (2009). Food and Agriculture Organization Corporate Statistical Database. Production Statistics. Live Animals. FAO Statistics Division. Rome: Food and Agriculture Organization of the United Nations (FAO) [Accessed 20 February 2013]. Retrieved from http://faostat.fao.org/site/ 573/default.aspx\#ancor

FAOSTAT. (2010). Production Statistics. Live Animals. FAO Statistics Division. Rome: Food and Agriculture Organization of the United Nations (FAO) [Accessed 20 February 2013]. Retrieved from http://faostat. fao . org / site / 573 / DesktopDefault . aspx? PageID $=573$ \# ancor

Farah, Z. (1996). Camel milk: properties and products. St. Gallen, Switzerland: Swiss Centre for Development Cooperation in Technology and Management (SKAT).

FDA. (2001). Food and Drug Administration. Bacteriological Analytical Manual Online. USA: Food and Drug Administration.

Goldman, E., \& Green, H. (2009). Practical handbook of microbiology. 2nd ed. Boca Raton: CRC Press, Taylor and Francis Group.

Harley, J., \& Prescott, L. (2002). Laboratory exercise in microbiology. 5th ed. USA: The McGraw-Hill Companies.

Hayes, M., \& Boor, K. (2001). Raw milk and fluid milk products. In: E.H. Marth \& J.L. Steele (Eds.), Applied dairy microbiology, 59-76. 
Quality and safety of camel milk $\mid 157$

Khaskheli, M., Arain, M., Chaudhry, S., Soomro, A., \& Qureshi, T. (2005). Physico-chemical quality of camel milk. Journal of Agriculture and Social Sciences, 1(2), 164-166.

Leclercq, A, Lambert, B, Pierard, D, \& Mahillon, J. (2001). Particular biochemical profiles for enterohemorrhagic Escherichia coli O157 : H7 isolates on the ID 32E system. Journal Of Clinical Microbiology, 39(3), 1161-1164. doi:10.1128/JCM.39.3.11611164.2001

McLandsborough, L. (2004). Food microbiology laboratory. Boca Raton: CRC Press LLC.

Merin, U, Sela, S, Rosen, B, Pinto, R, \& Leitner, G. (2005). Standards for camel milk. In B Faye \& P Esenov (Eds.), Desertification combat and food safety (pp. 146-151). Nato Science Series, Sub-series I: Life And Behavioural Sciences. Amsterdam: IOS Press.

O'Connor, C. (1995). Rural dairy technology. ILRI Training Manual. Addis Ababa, Ethiopia: International Livestock Research Institute.

Omer, R., \& Eltinay, A. (2008). Microbial quality of camel's raw milk in central and southern regions of united arab emirates. Emirates Journal of Food and Agriculture, 20(1), 7683.

Roberts, D., \& Greenwood, M. (2003). 3rd ed. oxford: blackwell publishing ltd. Practical Food Microbiology.

Semereab, T, \& Molla, B. (2001). Bacteriological quality of raw milk of camel (camelus dromedarius) in afar region (ethiopia). Journal of Camel Practice and Research, $8(1), 51-54$.

Tafesse, B., Mekuriaw, Z., \& Baars, R. (2002). Milk production performance of the onehumped camel (Camelus dromedarius) under pastoral management in semi-arid eastern Ethiopia. Livestock Production Science, $76,37-44$.

Yi-Wei, T., \& Stratton, C. (2006). Advanced techniques in diagnostic microbiology: biochemical-profile based microbial id system. New York: Springer.

Younan, M., Kenyanjui, M., Wangoh, J., Nganga, A., Farah, Z., Wasem, A., ... Bornstein, S. (2004). Camel milk hygiene and mastitis: Examples from Kenya and Soma- lia. In Lait De Chamelle Pour L'Afrique. Paper presented at Atelier sur la Filière Laitière Caméline en Afrique, held at Niamey, Niger, 5-8 November 2003 (pp. 8591). Rome: Food and Agriculture Organization of the United Nations. 